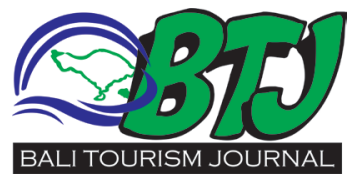

\section{The Existence of Tri Datu, From Temple's gift to Souvenir Industry}

\author{
Eka Ari Suhendra*
}

\section{ABSTRACT}

Consisting of three colors: red, white, and black, Tri Datu reflects three absolute powers surrounding the universe. Balinese Hindu people manifest the trinity deities into interwoven red, black and white threads. Almost in every Balinese Hindu ritual, the existence of the Tri Datu thread can be seen. Therefore, the Tri Datu thread has been using as a ritual instrument or protective amulet. On a philosophical level, the item has a value of self-control. If someone is wearing the sacred item, they would properly behave in society because the interwoven thread represents the divine symbol of righteousness. Many Balinese have been spotted wearing the three-colored thread, thus attracted the non-Balinese people curiosity. The phenomenon was perceived by wider communities that the interwoven thread is local identity. It is gradually led to market demand to obtain the Tri Datu as a souvenir from the island of God. One to another home industry of the Tri Datu accessories emerged as a response to tourism industry demand. Today, one may find the Tri Datu thread-based souvenir in the marketplace at ease. Although the interwoven thread strongly relates to religious symbols, it does not mean that non-Balinese cannot wear it. One should be aware that the Tri Datu holds a religious value that should be taken into account. Therefore, one should avoid wearing it inappropriately, such as a leg bracelet, or put it in any place without consulting it beforehand.

Keywords: Tri Datu, Souvenir, Temple

Cite This Article: Suhendra, E.A. 2021. The Existence of Tri Datu, From Temple's gift to Souvenir Industry. Bali Tourism Journal 5(1): 1-4. DOI: $10.36675 /$ btj.v5i1.50
Accepted: 2021-03-20

Published: 2021-04-02
Received: 2021-02-16

\section{THE CONCEPT OF TRI DATU}

In Hindu's teaching, three phases of life: birth, life, and death, are believed to be beyond human control. Throughout the history of humankind, Humans tend to manifest something from their imaginations. Thus they were called a homo empiricus, homo imaginarius, and homo symbolicum. ${ }^{1}$ With the limited ability of humans to control this phase of life, they practically believe that there is a higher power beyond their capability to regulate the birth, life, and death of mortal beings in the universe. This idea then gave birth to a Tri Murti concept. ${ }^{2}$ The concept expressed that the supreme being manifests the universe power into three figures: Brahma, Vishnu, and Shiva. Each figure then represents in color. Fire is associated with Brahma, the God of creation. Thus he is symbolized with red. Black color represents Vishnu, a symbol of fertility, duty, care and maintenance. Then white is for Shiva, the color representing cleanliness, beginning and end, the empty phase when living things reach their end of life. On a ritual level, Balinese Hindu people manifest the trinity deities into interwoven red, black and white threads commonly known by Balinese people as Tri Datu thread, or in some areas called

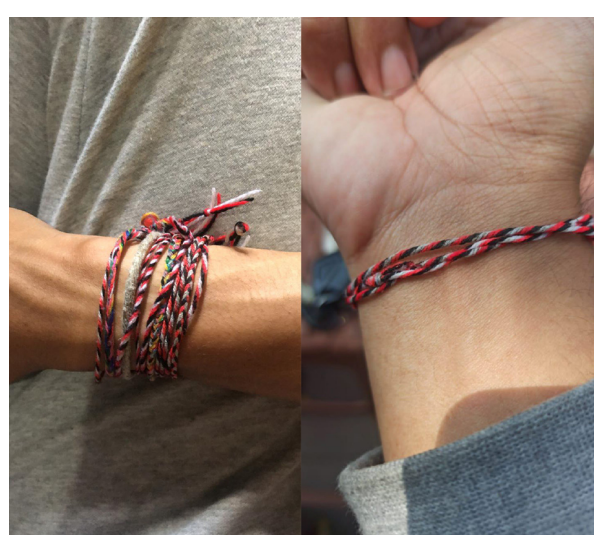

Figure 1. Tri Datu thread. Balinese Hindu people manifest the trinity deities into interwoven red, black and white threads commonly known by Balinese people as Tri Datu thread, or in some areas called Sridatu. ${ }^{4}$ received globally. 
Sridatu. The threads should be the same in size and woven like a hair braid. ${ }^{3}$

According to the existing historical record, it can be considered that the custom to wear the Tri Datu bracelet was strongly influenced by Hinduism after the Majapahit Empire conquest to Bali, at the set of Bedahulu kingdom. In the old Javanese manuscript dated $9^{\text {th }}$ to $11^{\text {th }}$ century, Agastya Parwa stated that the Tri Datu thread for humans protects themselves from hostile forces. Thus the humans can deflect negative influences and may act wisely. In essence, the Tri Datu thread is self-actualization in worshiping Tri Murti. Balinese Hindus perceive the bracelet imbued with mystical power as a symbol of the almighty God's protection. ${ }^{5}$

Meanwhile, the oldest Balinese historical record that mentions the thread's existence for the first time in history is Babad Dalem. The ancient manuscripts mentioned the Tri Datu usage was in the $14^{\text {th }}-15^{\text {th }}$ century, during King Dalem Waturenggong. At that time, the king was in the middle of a war with the king of Dalem Nusa kingdom, named Dalem Bungkut. When King Dalem Bungkut was defeated, a pact between Dalem Waturenggong and Dalem Bungkut was made. The defeated king ordered Ratu Gede Mecaling, his loyal warrior, to create deadly epidemics targeting people on Bali's mainland every year. As a repellent, they were required to perform offering rituals and wear a Tri Datu bracelet as a symbol of devotion to the Creator. Over time, the thread is recognized as an identity symbol of Balinese Hindus. ${ }^{6}$

Some scholars believe the three colored threads have been long used in Hindu religious practices. Dr. Ida Bagus Subrahmaniam Saitya, SH, S.Ag., M.Fil.H., from I Gusti Bagus Sugriwa Hindu State University revealed, the instrument can be seen at mendem pedagingan (foundation stone laying ceremony). At the ceremony, the stone is convoluted by the Tri Datu thread. Other ceremonies such as Pemangku initiation and student commencement also incorporated the usage of this religious item. ${ }^{7}$ Further explanation was given by Bali Province PHDI chairman, Prof I Gusti Ngurah Sudiana. He mentioned that wearing Tri Datu-colored threads means binding

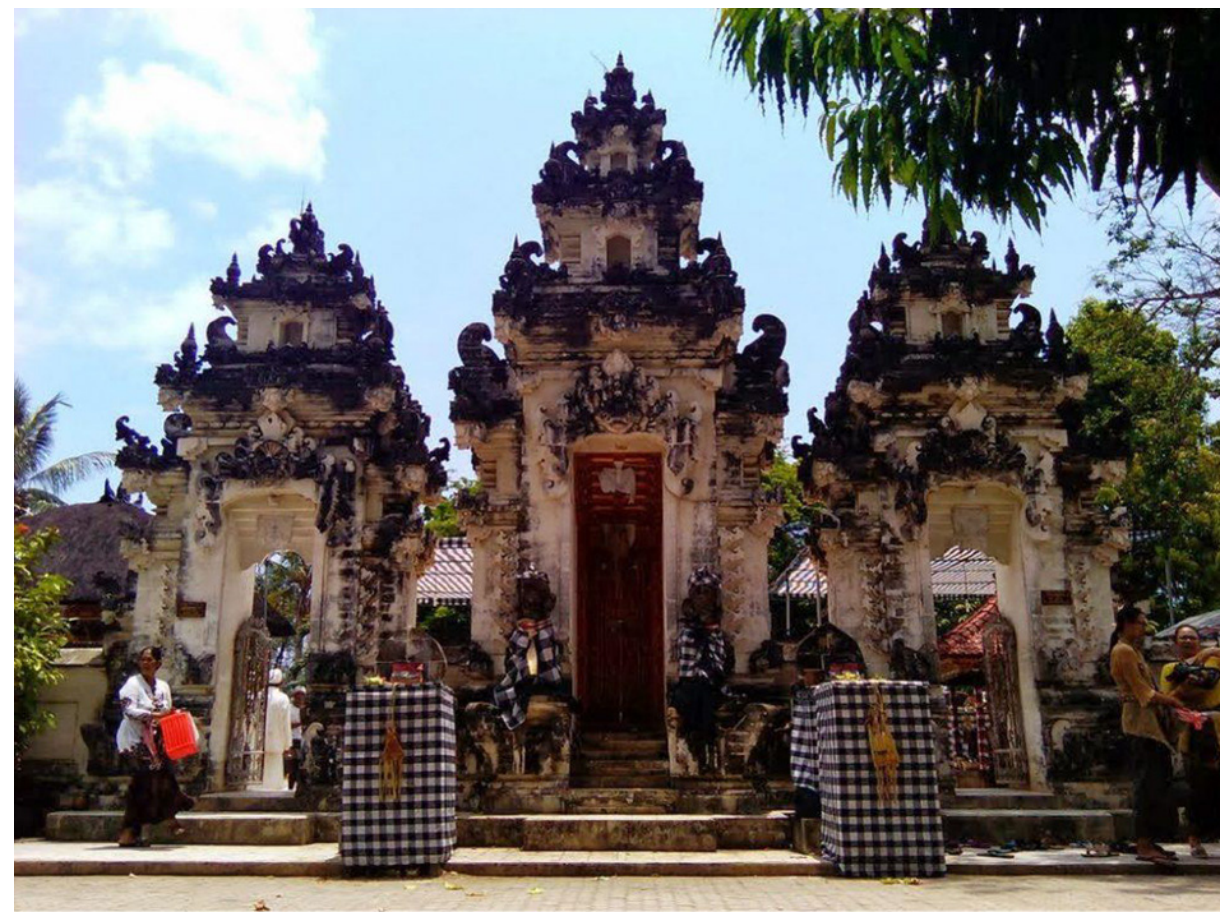

Figure 2. Dalem Ped Temple ${ }^{11}$

oneself to religious norms. Almost all Yadnya rituals required braided thread availability. Starting from the Dewa Yadnya ceremony, the instrument serves as the supreme being, Ida Sang Hyang Widhi, with all of the manifestations' guides. In the Butha Yadnya ceremony, the Tri Datu serves as a pamogpog (Complement) if the offerings were inadequate. In Rsi Yadnya, the interwoven thread would be coiled up on the student body by the teacher as a symbol of a gift. Meanwhile, in the Manusa Yadnya ceremony, the Tri Datu thread is used as a symbol of blessing. Furthermore, at the Pitra Yadnya ceremony, the Tri Datu thread guides the deceased soul to reach the afterlife. ${ }^{8}$

\section{TEMPLE'S GIFT FOR THE PILGRIM}

The existence of Dalem Ped Temple in Nusa Penida island serves as the central place where the origin of the Tri Datu thread as a gift started. Dalem Ped Temple is the Temple of Ratu Gede Mecaling. A pilgrim who prayed at the Temple would be granted a Tri Datu thread as a symbol of protection; then, it has been a recurring gift from the Temple until nowadays. ${ }^{9}$ Some temples then started to give similar items to every pilgrim who visits the holy place.
Likewise, some shamans grant amulet in the form of a Tri Datu bracelet to deal with the patient's disease or misfortune. The amulet has magical powers as a repellent. The user of the amulet will be protected from danger originating from humans, such as black magic or the netherworld's curses. ${ }^{10}$

Along with the popularity of wearing the Tri Datu bracelet, this trend has been experiencing developments, starting from the number of colors in the threads and other supplementary materials to elevate the accessories' aesthetic appearance. For example, in 2015, Besakih Temple gifted nine colors of interwoven thread namely Sanga Datu to the pilgrims. ${ }^{12}$ Meanwhile, some temples give four-colored, fivecolored, or nine-colored interwoven threads as a gift. However, it serves as an accessory gift from the Temple, unlike the Tri Datu, which serves as an essential ritual instrument. The additional colors in the thread were based on the representation of Dewata Nawa Sanga, the nine rulers of the cardinal directions.

Since it has such a profound meaning, Balinese Tri Datu bracelets are often worn by Balinese people when holding religious ceremonies. Nowadays, almost all religious ceremonies in Bali are accompanied by the participants' wearing of the Tri Datu 


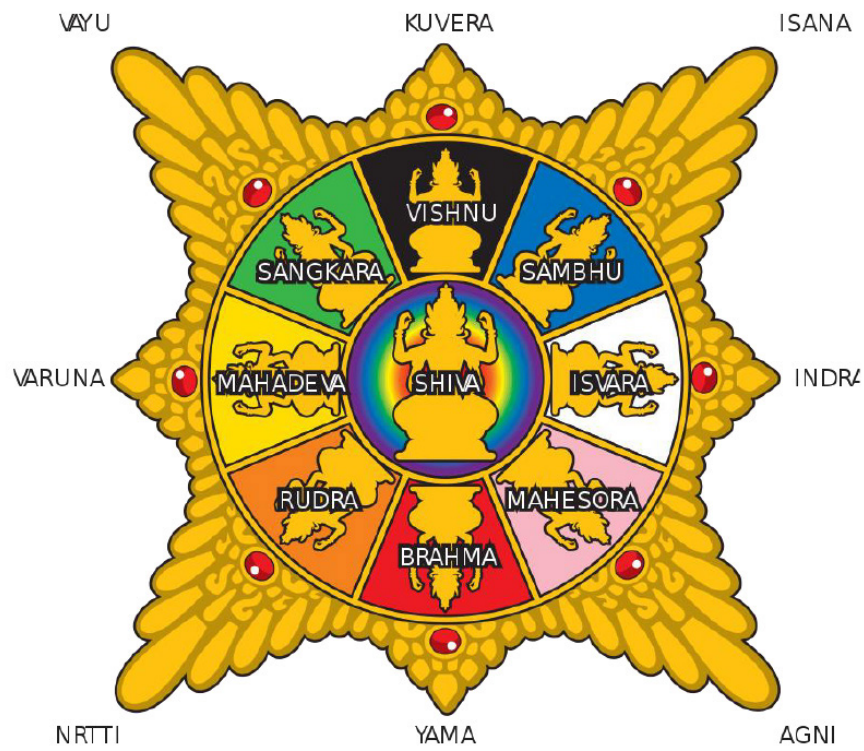

Figure 3. Dewata Nawa Sanga, the nine rulers of the cardinal directions. ${ }^{13}$
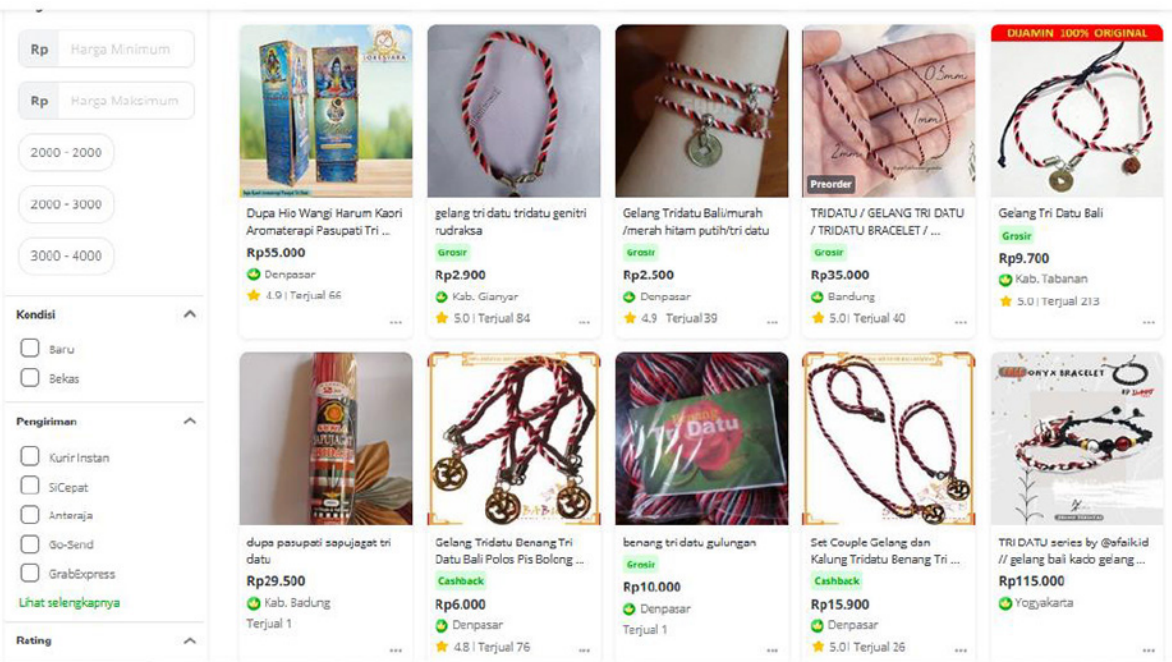

Figure 4. Tri Datu in Market Place ${ }^{17}$

bracelet. Tri Datu is philosophically more than just a protection charm. The thread has a philosophical meaning as a form of self-control. The primary material of the bracelet is a rope, with its primary function to bind. Thus, it is expected that the wearer would bind their lust and control their mind. If someone uses the Tri Datu thread, it is expected that the item would affect the user's behavior since they wore divine symbols. Therefore, the person would consciously behave and be fully committed to righteousness path. ${ }^{14}$

\section{FROM TEMPLE'S GIFT TO SOUVENIR INDUSTRY}

The bracelet's existence gradually attracts the interest of the wider non-Balinese community, both local and international tourists. They perceive the bracelet as a local cultural identity. As a result of globalization, social change has made the Tri Datu bracelet a commodity to integrate with business activities. As a result, Tri Datu's bracelet has turned into popular culture. An item is classified as part of popular culture when Its characteristics are mass-produced, profit-oriented, and widely used. The user motive is more emphasis on pleasure. ${ }^{15}$ One by one, Tri Datu home-based industry sprouts in many areas around Bali to fulfill the market demand for this new attractive gift from Bali. Nowadays, people do not need to undergo prayer rituals or visit holy places to obtain one. They may obtain the bracelet with additional Ongkara letter plates, perforated money, or any Hindurelated religious symbol by purchasing it at a souvenir shop or online marketplace. ${ }^{16}$

The Tri Datu bracelet as pop culture is the result of the creative industry. Its production process combines various existing aspects in Balinese society with the aesthetic presentation. Furthermore, the item is added with a variety of new creativity, thus enriched its value. Combining attractive packages with vivid explanations in many languages, brand sentimental marketing strategy, and exact price made the commodities a valuable gift that hard to resist. Although the Tri Datu no longer only serves as a religious instrument, broader society is expected to wear it properly. ${ }^{18}$

According to Bali Province PHDI chairman, Prof I Gusti Ngurah Sudiana, nothing was wrong if non-Balinese wear Tri Datu. However, he emphasizes that one should know how to use the three-colored thread-based accessory. For instance, Sudiana explained that someone should avoid wearing it as a leg bracelet because it would be prone to infuriate Balinese society. The simple reason because the thread's initial function is a sacred symbol of Tri Murti. Therefore, if someone misused Tri Datu, either they obtain it from ritual or marketplace can violate the local belief and their identity. ${ }^{3}$

\section{CONCLUSION}

Dalem Ped Temple in Nusa Penida has been well-known to be the first Temple that grants its pilgrim the Tri Datu thread. The custom then spread to many temples around Bali. The indigenous healer or shaman often gives the Tri Datu thread a symbol of protection to their patients. Furthermore, Almost in every Balinese Hindu ritual, the existence of the Tri Datu 
thread can be seen. Therefore, the Tri Datu thread has been using as a ritual instrument or protective amulet. On a philosophical level, the item has a value of self-control. If someone is wearing the sacred item, they would properly behave in society because the interwoven thread represents the divine symbol of righteousness.

Many Balinese have been spotted wearing the three-colored thread, thus attracted the non-Balinese people curiosity. The phenomenon was perceived by wider communities that the interwoven thread is local identity. It is gradually led to market demand to obtain the Tri Datu as a souvenir from the island of God. One to another home industry of the Tri Datu accessories emerged as a response to tourism industry demand. Today, one may find the Tri Datu thread-based accessories in the marketplace at ease. Although the interwoven thread strongly relates to religious symbols, it does not mean that non-Balinese cannot wear it. Bali Province PHDI chairman, Prof I Gusti Ngurah Sudiana, pointed out that one should be aware that the Tri Datu holds a religious value that should be taken into account. Therefore, one should avoid wearing it inappropriately, such as a leg bracelet, or put it in any place without consulting it beforehand.

\section{REFERENCES:}

1. ATMADJA, Anantawikrama T.; RAI, I. Wayan. Bisnis Gelang Tri Datu sebagai Budaya Populer pada Masyarakat Bali. In: Seminar Nasional Riset Inovatif. 2017. p. 405-412.

2. WATRA, I. Wayan. Tri Murti Ideologi Sosioreligius Mempersatukan Sekte-sekte Di Bali. Dharmasmrti: Jurnal Ilmu Agama dan Kebudayaan, 2018, 18.2: 114-121.

3. IP Suyatra. Ini Makna, Tujuan dan Cara Penggunaan Benang Tri Datu. Bali Express. 2017. Available at URL: https://baliexpress. jawapos.com/read/2017/11/19/27782/inimakna-tujuan-dan-cara-penggunaan-benangtri-datu

4. Image of Tri Datu. 2021. Personal Collection.

5. Anonymous. Makna Dan Fungsi Benang Tri Datu. Dharmadana[dot]id. 2019. Available at URL: $\quad$ https://dharmadana.id/makna-danfungsi-benang-tri-datu/

6. IBR Putra. Babad Dalem. Bali Upada: Sastra. 1991.

7. Yulia. Benang Tridatu, Filosofi Oleh-Oleh Tangkil Hingga Trend Aksesori. Nusa Bali. 2019. Available at URL: https://www.nusabali. com/berita/57256/benang-tridatu-filosofioleh-oleh-tangkil-hingga-trend-aksesori

8. Kemenag Gianyar. Sirogi "Uniknya Benang Tri Datu”. KEMENTERIAN AGAMA REPUBLIK INDONESIA KANTOR KABUPATEN GIANYAR. 2020. Available at URL: https://bali. kemenag.go.id/gianyar/berita/13946/sirogiuniknya-benang-tri-datu

9. SETIAWAN, Ida Bagus Putra. Nangluk Mrana in Intaran Community; The Modern and Old perspectives. Bali Tourism Journal, 2019, 2.1: 41-44.
10. Atmadja, Nengah Bawa, Luh Putu Sendratari, dan I Wayan Rai. 2015. "Deconstructing Gender Stereotypes in Leak" Jurnal Komunitas 7(1)(2015). Halaman: 71-78

11. Image by IK Ramadana 'Pura Dalem Ped Nusa Penida'. Nusapenida[dot]id. 2019. Available at URL: https://nusapenida.id/pura-dalem-pednusa-penida/

12. AAPS Putra, S Rohim. Pertama Kali, Ribuan Benang Sanga Datu Dibagikan untuk Pamedek. Tribun Bali. 2015. Available at URL: https:// bali.tribunnews.com/2015/04/04/pertama-kaliribuan-benang-sanga-datu-dibagikan-untukpamedek

13. Image Surya Majapahit by G Kartapranata. 2009. Available at URL: https://id.wikipedia. org/wiki/Berkas:Surya Majapahit Diagram. svg.

14. Putrawan. Benang Tri Dathu sebagai Simbol Omkara dan Proteksi Gaib. Majalah Hindu Raditya,2012, Vol86.

15. Atmadja, NB dan L.P.S. Ariyani. Sosiologi Media Perspektif Teori Kritis. 2016.

16. SUDARMANA, Ida Bagus Made; ARJAWA, I. Gusti Putu Bagus Suka; MAHADEWI, Ni Made Anggita Sastri. KOMODIFIKASI GELANG BENANG TRIDATU DALAM INDUSTRI PARIWISATA BALI.

17. Image of Tokopedia Marketplace Screenshot. 2021. Personal Collection.

18. I Baihaki. Gelang Tri Datu Khas Bali, Bukan Sekadar Aksesoris, Ada Makna Penting di Dalamnya. Kintamani[dot]id. 2018. Available at URL: https://www.kintamani.id/gelang-tridatu-khas-bali-bukan-sekadar-aksesoris-adamakna-penting-di-dalamnya

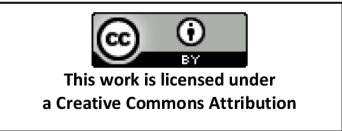

